\title{
APPETITE INHIBITORS CLASSIFIED AS ONE OF CONDITIONS RELATED TO DEVELOPMENT OF PULMONARY HYPERTENSION
}

Clecilene Gomes Carvalho ${ }^{1}$

Sérgio Ricardo Magalhães ${ }^{2}$

\begin{abstract}
${ }^{1}$ Graduated in Nursing by College 'Universidade do Vale do Rio Verde' (UNINCOR), campus Betim city. Member Association of Pulmonary Hypertension of the state Minas Gerais (AMIHAP). Post-graduation student in Multifocal Psychology. E-mail: clecilene@globo.com

${ }^{2}$ Graduated in Mathematics, teaching of Nursing course of College 'Universidade do Vale do Rio Verde' (UNINCOR), campus Betim city. $\mathrm{PhD}$ in Biomedical Engeneering. E-mail: sergio.magalhães@unincor.edu.br
\end{abstract}

\begin{abstract}
The Brazilian population leads the world in consumption of appetite suppressants/ anorectics. Prolonged use of appetite suppressants can cause pulmonary arterial hypertension (PAH), a chronic and disabling. Taking into consideration the large intake of appetite suppressants in Brazil and the fact that these are, according to the WHO, among the conditions related to the incidence of pulmonary hypertension and given the seriousness of this condition to the carrier, saw the need to conduct a literature review on the adverse effects of these drugs, and know what are the risks of imminent health and also seek information about the HAP, with the aim of adding knowledge to nursing professionals to enable the health education regarding the conscious use of appetite suppressants and stimulate the search for information about a serious illness and so little known in nursing as PAH.
\end{abstract}

Keywords: Appetite Depressants. Hypertension Pulmonary. Obesity. Nursing care.

\section{INTRODUCTION}

Brazilian population leads world market in consumption of appetite suppressants and anorectics. In 2009, 3 tons of Anfepramona, 1.8 tons of Sibutramine, one ton of Femproporex and 2 kilos of Mazindol were sold in Brazil (FENAPAR, 2011). The problem is because of many times the use of these medicines is made without medical supervision. (COTA; MOURA; GOMES, 2008).
In Brazil, the law that approves the technician rules about substances and medicines under special control is the law number 344/98 - SUS/MS of May $12^{\text {th }}$, 1998, that defines the following substances: A1 and A2 (Narcotics), A3, B1 and B2 (Psychotropic); C1 (other substances under special control); C2 (Retinoics for systemic use); C (Immunossupressant). Appetite suppressants are classified as psychotropic drugs and are prescript in a blue prescription (ANVISA, 2011). 
There are many medicines used as anorectics, among them Anfepramona, Manzidol, Femproporex and Sibutramine. Side effects shown are mental confusion or depression; rashees or hives, fever, neurological excitation, psychotic outbreak, violent behavior, suicidal or homicidal ideas vessel heart implications, tachycardia, hypertension(COTA; MOURA; GOMES, 2008).

The prolonged use of anorectics can cause Pulmonary Arterial Hypertension (PAH) (ANVISA, 2011). The PAH is defined as an circulatory abnormality characterized by an increasing of the vessel resistance in the small blooding, in general by mixed means involving Vasoconstriction, remodeling of vessel walls and thromboses in situ. The progressive increase of the Pulmonary Vessel Resistance (PVR) drives to Right Ventricle Failure (RVF) and premature death. (CALLOU; RAMOS, 2009)

A primary PAH epidemic occurred in Europe in 1960, associated to the anorectics use made that many countries aroused to the big risk of theses medicines to the population. European countries don't use Anfepramona, Femproporex and Manzidol as anorectics since 1999. In the United States those medicines never have been registered since January 2010. Europe doesn't have Sibutramine in its market. The USA canceled Sibutramine register in October 2010. But in Brazil, the consumption of these medicines is too high (ANVISA, 2011). In 2010 were sold in Brazil 6.368.547 pills and derivates of amphetamine and consumption tends to increase, considering that, according to Health Ministry, $56,3 \%$ of the Brazilian population is overweight (FENAFAR, 2011).

Taking the big consumption of anorectics into consideration in Brazil and to the fact that they be, according to WHO, among the causes of PHA and because of the seriousness of this illness to the people, took the necessity to do a job of bibliographic revision of the side effects of these medicines. As well as to know the probable risks to the health an also seek information about PHA. The purpose of this revision study was to gather knowledge for nursing professionals in order to make possible education about health specially about the aware use of the anorectics and to propose seek for information about a seriousness illness and so less spread in Nursing as PHA.

\section{METHODOLOGY}

Besides the use of the technique not about the efficiency and security of the anorectics drew up by the National Agency of Sanitary Surveillance (ANVISA)NASS and published in the beginning of 2011, also was carried out a survey in magazines related to the data of La Literatura Latino Americana y do Caribe en Ciencias de la Salud (LILACS), Scientific Eletronic Library Online 
(SCIELO), National Library of Medicine (MEDLINE); Caribean and Latin American Information Center in Health Science (BIREME); in order to reach the aims settled, and give a scientific aspect to the bibliographic revision.

The uniterms selected to the referential search were: appetite suppressants, anorectics, Pulmonary Arterial Hypertension, Nursing assistance, side effects.

The combination of terms among them was used as a strategy of seek in the basis that permitted this use, in order to make easy the search and to construct the theoretical validity of the research from solid base of the knowledge. The works that would be used in the referential initially were picked up by the reading of the title and the abstract of the searched articles.

So, 32 articles have been collected and after that, they have been read, identifying the subject matters and evaluated the sense cores that mentioned to the referred theme in the bibliographic revision and that settled into the period between 2008 and 2011.

The articles that didn't offer subsides to the study or weren't a search objected were excluded.

\section{LITERATURE REVIEW}

Brazil is one of the biggest consuming countries of appetite suppressants and most part of this consumption is related to obesity control (SISENANDO, 2010). Since 1988, we can see a raised and growing consumption of anorectics in Brazil, considering about ten Definite Daily Doses (DDD) per one thousand inhabitants. For each group of one thousand Brazilians, there was a daily consumption of ten doses of anorectics. In contrast to the Brazilian situation, in Europe, in the 1980's, the consumption of psycostimulants were only 0,5 DDD/thousand inhabitants, and in 1993 this consumption already was considered so insignificant, that the quantities were insufficient to the calculation of the DDD. In a report spread by the International Narcotics Inspection Board (INIB), organization subordinate to United Nation (UN), that point out the risks of the growing of the consumption of anorectics in Brazil in order to lose weight. According to the report, there was a rise of $500 \%$ in the consumption of anorectics in Brazil since 1998, and this pattern of consumption is unacceptable and must be stopped. (CARNEIRO; GUERRA JÚNIOR, ACÚRCIO, 2008)

Also according to the authors above, this context sport the necessity of regulation of the relationship between production and consumption, this is the origin of the most part of the health problem. The intervention must be done by the Sanitary Surveillance, that has legal instruments to protect population's health. Specifically to the medicines, sanitary regulation becomes very 
relevant, because of the medicines, paradoxically, despite to be considered and essential product to the actions for the population's health, they are produced by companies that wish revenue and they are far of the construction process of Health Unique System (HUS).

The anorectic drugs as amphetamine don't act only reducing the appetite, but they make a central stimulating Cardiovascular system. All simpathomimetics imitate the effects of adrenalin, noradrenalin and Dopamine. These substances promote the increasing of the blood pressure and heart beating, bronchial dilation, peripheral constriction of blood vessels, Dilation of Pupils, empting of bladder and intestines, attention increasing stimuli sensitivity, loss of appetite and self-confidence increasing. The result of the consumption of amphetamines is hungry and sleeps loss and a strong need of movement, decreasing of fatigue, euphoria and thinking accelation. (CARNEIRO; GUERRA JUNIOR; ACURCIO, 2008; MOREIRA; GADANI, 2009).

A study carried out in São Paulo that analyzed 108.615 prescriptions of Psychotropics medicines, 26.930 were related to anorectics substances, mainly Dietilporopione (Amphepramone) and Femproporex. Femproporex has presented special importance in Brazil. Despite this medicines must be prescripted under specific legislation; many people use them illegally because of them stimulant properties. However were checked into the last years the illegal use of Femproporex by truck drivers (they call it "rivet"). They can buy it even in post offices or different places on the Brazilian roads(SISENANDO, 2010). They use these medicines in order to be awake for a long time (PENTEADO, 2008). But this objective is reached only a few hours, after that, comes irritability and a deep sleep. There are many truck crashes because of truck drives suffer drowsiness and sleep when they are driving. (MOREIRA; GADANI, 2009).

More young people are abusing of amphetamines. It's worrying, because over the years most of them tend to be addicted. Many of them raise the doses and acquire health complications. The Cardiotoxicity associated to the use of amphetamines can be shown as IAM, cardiomyopathy or arrythymia. Amphetamine is a simpathomimetic and increases the levels of noradrenaline and can cause vasospasm. Therefore can lead indirectly do coronary vasoconstriction, resulting in heart attack. Besides, cause liberation of catecholamines in the nervous endings pre synaptics, stimuling $\alpha$ and $\beta$ adrenergics, that cause tachycardia and arterial hypertension. Other actions of amphetamine include platelet aggregation induced by catecholamines, with subsequent formation of thrombus and atherosclerotic plaque rupture, and myocardial necrosis and increased myocardial oxygen demand. These 
mechanisms can explain the pathophysiology of IAM induced by the substance. (CARNEIRO; GUERRA JUNIOR; ACURCIO, 2008; OLIVEIRA, 2010).

They are not indicated to children, people who have heart disease and arterial hypertension. The following substances and their maximum daily doses are marketed in Brazil under prescription B2: Femproporex (50mg), Anfepramona (120 mg) and Mazindol (3 mg). The last one can't be used more than 3 months (QUEIROZ, 2008).

Also according to the author above, Sibutramine is also derivate from $\beta$ phenethrylamine, it's a appetite suppressant of central action that inhibits the reuptake of norepireprhine, serotonine and dopamine, increases satiety and norepireprhine and increases metabolic rates. The side effects are dry mouth, constipation, tachiycardia,sweating, and could occur increasing of arterial pressure. Dose varies from 10 to $15 \mathrm{mg}$ per day.

Manzidol has already a different molecular structure of amphetamine medicines. It is considered an imidazoisoindol. It is an appetite suppressant that inhibits reuptaken of serotonin and Noropinefrina and inhibits the dopamine. It also inhibits directly the activity of the neurons sensible to glucose in the side hypothalamus, resulting from inhibition of gastric secretion. It can present cardiovascular effects, rising of arterial pressure, severe primary depression and drive do maniac phase. (ANVISA, 2011).

Another condition associated with the use of long-term anorectic is $\mathrm{PAH}$ (pulmonary arterial hypertension), a rare, little known and extremely serious, with estimated annual incidence of between one and two per 1000 inhabitants per year and represents a significant risk of death (ABRAF, 2011). It appears as a consequence of the rising of the blood pressure into the arteries, due to vessel narrowing that drives the blood from the heart to the lungs. The consequence of the rising of the pressure in the ventricle is its death, because it can't support the pressure rising. (MENEZES, 2008).

The diagnosis standards are: systolic pressure of pulmonary artery (SPPA) > $30 \mathrm{mmHg}$ and diastolic (DPPA) > 15mmHg; medium pressure into pulmonary artery (MPPA) > $25 \mathrm{mmHg}$ at rest, or $>30 \mathrm{mmHg}$ during exercises. Studies developed since 1996 proved that the use for more than 3 months of these drugs can provoke the illness. (CALLOU; RAMOS, 2009).

Amfepramona drives to primary $\mathrm{PAH}$ because it promotes the mutation of the genes BMPR2, and can occur in a short time. This mutation drives to the lost of the function of the gene, altering the formation of the factor of growing in the arterial pulmonary endothelium and muscle cells, resulting in an increasing of cell proliferation. From $10 \%$ to $20 \%$ of the individual who carry this mutation 
can develop primary PAH. However it can provokes secondary PAH in a possible new model in which can interact genetic factor and environmental in its pathogenesis. Femproporex, Sibutamine and Manzidol are also associated to PAH. (ANVISA, 2011).

The symptoms and signs of $\mathrm{PAH}$ are gradual shortening breathing that can be worst with exercises, thoracic pain, fatigue, leg swelling, persistent cough, palpitation, cyanosis, dizziness, faint (MENEZES, 2008).

The early symptoms of PAH (such as dyspnea, dizziness and fatigue) are often mild and are common to several other conditions, for example, lack of physicalfitness and asthma. At rest, there are often no symptoms and no apparent signs of disease. As a result, the diagnosis may be delayed for months or even years, which means that PAH is often not recognized until the disease is relatively advanced. (MENEZES, 2008; AMIHAP, 2011; ABRAF, 2011).

It's known that PAH is a disease of hard diagnosis, but is necessary that the nursing stay alert. Since through nursing care, the nurse has an important role in the orientation of the people about the indiscriminate use of the appetite suppressants, mainly when used without indication for obesity treatment, they can orient also about the side effects and complications from these drugs and incentive the patient to change his/her style. Nurse is the professional who spends more time with the patient that makes him/her even more responsible for knowledge acquisition. So this professional $\mathrm{e}$ the other ones must seek always continued education, in order to, as team, can identify early any alteration that could show up. (COTA; MOURA; GOMES, 2008)

\section{RESULTS AND DISCUSSION}

Many articles were found related to the use of anorectics and their implications to the health, but, for being a new theme, there are few articles relating the use of these drugs with PAH. All of the articles found related to the role of Nursing assistance to PAH focused the issue of the occurrence of this illness in babies. Any article was found emphasizing the role of Nursing for aware education of the use of the anorectics having as reference the PAH.

The drug therapy to obesity must be associated to changes in one's life style (a better diet, practice of physical activities and behavior affective-cognitive therapies), because of when the individual stops the use of the loss-weight medicine, he/she gains weight again. For this reason, loss-weight drugs shouldn't be used only for aesthetic reasons (TOLEDO, 2010).

Nutritional orientations associated to incentive to physical activities are the basis to the obesity treatment. Antiobesity drugs are recommended to the people who, after nondrug treatment, keep Body mass index (BMI) 
$>30 \mathrm{~kg} / \mathrm{m} 2$ or between $25 \mathrm{~kg} / \mathrm{m} 2$ and 30 $\mathrm{kg} / \mathrm{m} 2$ facing comorbidities (OLIVEIRA, 2010).

The problem is that not always the recommendations are respected, what is proved by a study about the use of medicines to weight-loss BMI among college students in Vale do Araguaia (MT/GO), that concluded that among the students that used weight-loss medicines, part of them did it for aesthetic reasons, and are individuals who have BMI normal, i.e., they aren't recommended to the use of these medicines (TOLEDO, 2010).

Given the indiscriminate use and its varied effects, as well as the association with serious illness, becomes urgent the improvement of the actions of the health surveillance in order to improving the control and inspection of these substances, interfering in its trade to promote the building of a more rational access.

Due to the risks of these medicines, the National Agency of Sanitary Surveillance (NASS) published in 2011 a technique note about the efficiency and security of the appetite suppressants, in order to justify the reason of Amfepramona, Femproporex, Sibutramine and Manzidol no more present a good cost/risk relation, what makes the stay of these medicines in the market impossible (ANVISA, 2011).

The NASS' argument in the note is that these medicines are already forbidden in the United States and Europe, and besides they increase the risk of heart attack and be less effective in the maintaining weight reduction in a long term, those substances might bring risks to the lungs, heart and central nervous system. Among many justifications NASS cited appetite suppressants as a factor related to the appearing of PAH.

During session in the Legislative Chamber, one of the members raised the question to the fact that, at the same time the prohibition is important to preserve the people's integrity, it is necessary give attention to the consequences of this act, since it can drives to an appearing of a parallel market. One of the members of NASS affirmed that their aim is guarantee health security of the population. Despite been under control for more 20 years, appetite suppressants are consumed in huge scale. In 2010 there were 4.416 .790 prescriptions of these medicines (BRASIL, 2011).

However, October $4^{\text {th }} 2011$, NASS decide to take off Femproporex, Mazindol and Anfepramone, suppressants amphetaminic type, from the market. According to the decision, these medicines had their registers canceled, and it's prohibited the production, trade, handling and use of these products. But, for 3 voting to 1, it was decided that Sibutramine stays in the market, but under restrictions (ANVISA, 2011).

According to president-diretor of ANVISA (NASS), Dirceu Barbano, 
Sibutramine will be observed for 12 months, after this period, will be made a new evaluation of the medicine and then will be decided to keep or not the trade of the medicine. Due to restrictions, Sibutramine, classified as a medicine of the group B2, that need special prescriptions, from now both doctors and patients also must assign a commitment term. This term states that the doctor has explained the risks on using Sibutramine. There will be 3 copies: one for the drugstore, one for the patient and one for the doctor (ANVISA, 2011; G1, 2011).

Another important factor is that the laboratories which make or trade sibutramine must follow possible side effects and communicate to NASS (ANVISA), in case of occurrences. So, it's very important notify any problems to NASS, because the decision related to keep on selling this drug depends on the evaluation of risks and benefits to the patients, and it makes notifications one of the fundamental point for NASS' decision after stipulated within 12 months. It's much important to pay attention whereas Sibutramine has as side effect tachycardia and could drive to rising of arterial pressure (ANVISA, 2011).

However, it's important spot that the ideal anti-obesity drug must be safe, has a long-term action, or act indefinitely, offers bigger benefit than a diet, exercises and behavior changing, drives to weight-loss, in a year, 5\% higher than the one provoked by placebo, reduce or stop, if possible, comorbities. But this drug doesn't exist yet. (QUEIROZ, 2008).

Expected to after the prohibition of medicines Femproporex, Mazindol and Amfepramona, be intensified the inspection, in order to avoid illegal trade.

Regarding to the non-prohibition of Sibutramine, it's necessary that restrictions are really respected, besides, it's primordial an action in group involving doctors, nurses, health professionals in general, Education institutions, strengthening the combat to the use in excess and anti- ethic of appetite suppressants.

In relation to $\mathrm{PAH}$, was proved by the inexistence of articles on Nursing, that is very important that Nursing professionals look at this illness with more attention and criticism. Due to the difficulty on diagnosis PAH at the beginning is much more important that health professional seek information about this illness and of the factors related to its development, seeking and spreading knowledge, whereas the studies are important to educate health professionals how is the best way to look after these patients and about seriousness and complexity of clinic condition.

Known to the Nurse have to use Nursing process as assistance methodology for planning and implementation of nursing care. Taking the individualized process, planned, evaluated and principally continuous to 
improvement of the life quality of the people who use appetite suppressants and in this way can be able to do a holistic and humanized health care, looking after human being is his/her totality.

However, nursing professionals have to assume the commitment to spread the acquired knowledge. It's urgent and necessary write articles by these professionals not only focusing assistance about the use of appetite suppressants and $\mathrm{PAH}$, but in whole areas of their activity.

\section{REFERENCES}

ABRAF. Brazilian Association of Family and Friends of Individuals who suffer PAH. Maria Virginia Tavares Santana. Treatment of Pulmonary Arterial Hypertension. São Paulo, 2011. Available at: http://www.respirareviver.org.br/patologia.ht m. Acess: 05 may 2011.

AMIHAP. Mineira Association of PH. O que é a Hipertensão Arterial Pulmonar (HAP)? Minas Gerais, 2011. Available at: http://www.amihap.com.br. Acess 04 may 2011.

ANVISA. National Agency of Sanitary Surveillance. Technical note about appetite suppressants. Brasília, 2011. Available at: http://portal.anvisa.gov.br/wps/wcm/connect/c 53fdd0045d07478be65bfe99fa014e7/Avalia\% C3\%A7\%C3\%A3o+de+efic\%C3\%A1cia+e+s eguran\%C3\%A7a+dos+medicamentos+inibid ores+do+apetite+Final.pdf?MOD=AJPERES. Acess: 02 may 2011.

ANVISA. National Agency of Sanitary Surveillance. ANVISA keeps register of sibutramina and cancel amphetamines. Brasília, 2011. Available at: http://portal.anvisa.gov.br/wps/portal/anvisa/a
nvisa/home/!ut/p/c5/04_SB8K8xLLM9MSSz Py8xBz9CP0os3hnd0cPE3MfAwMDMydnA 093Uz8z00B_AwN_Q_1wkA48Kowg8gY4g KOBvp9Hfm6qfkF2dpqjo6IiAJYj_8M!/dl3/d 3/L2dBISEvZ0FBIS9nQSEh/. Acess: 06 oct. 2011.

BRASIL. Chamber of Representatives. Endocrinologistas criticam proibição da ANVISA a inibidores de apetite. Brasília, 2011. Available at:

http://www2.camara.gov.br/agencia/noticias/S AUDE/195184-ENDOCRINOLOGISTASCRITICAM-PROIBICAO-DA-ANVISA-AINIBIDORES-DE-APETITE.html. Acess: 05 may 2011.

CARNEIRO, Mônica de Fátima Gontijo; GUERRA JUNIOR, Augusto Afonso; ACURCIO, Francisco de Assis. Prescription, dispensing, and regulation ofpsychoactive anorexigenic drugs in Belo Horizonte, Minas Gerais, Brazil. Cad. Saúde Pública, Rio de Janeiro, 24(8):1763-1772, ago, 2008.

COTA, Ana P; MOURA, Gilliardia F; GOMES, Everton T. Of short-term appetite inhibitors drugs: a descriptive Study of the nursing students from Centro Universitário do

Leste de Minas Gerais - Unileste-MG. Rev. Enf. Integ., Ipatinga, 1 (1): 1-10, dec, 2008.

FENAFAR. National Federation of Pharmaceutical. Anvisa held hearings on the use of appetite suppressantes. São Paulo, 2011. Available at:

http://www.fenafar.org.br/portal/medicamento s/62-medicaments/758-anvisa-promoveuaudiencia-sobre-uso-de-anorexigenos.html. Acess: 02 may 2011.

QUEIROZ, Danícia Lobão. Pharmacotherapy of obesity. Brasília Méd,45(3):191-197, 2008.

MENEZES, Paulo. What you need to know about pulmonary arterial hypertension : projecting light on a serious illness and so little known. São Paulo: Empresa Jornalística Marconi, 2008. 
MOREIRA, Renata S.; GADANI, Julice A.A.B.. The prevalence of use of amphetamines by truckers passing through Dourados-MS City. Interbio, (3) 2: 27-34, 2009. Available at:

http://www.unigran.br/interbio/vol3_num2/ar quivos/artigo4.pdf. Acess: 21 sep. 2011.

OLIVEIRA, Fernanda B. et al. Acute Myocardial Infarction after Taking Amphepramone. Rev Bras Cardiol., Rio de Janeiro, 6(23):362-364, nov.-dec., 2010.

PENTEADO, Regina Zanella et al . Work and health of truck drivers in the state of São Paulo. Saude soc., São Paulo, 17(4): 35-45, dec, 2008 . Available at:

$<$ http://www.scielo.br/scielo.php?script=sci_a rttext\&pid=S0104-

$12902008000400005 \& \operatorname{lng}=$ en\&nrm=iso. Acess 21 september 2011.

SISENANDO, Herbert Ary. Profile of anorectic drugs dispensed in drugstore in Natal City/Brazil. Rev. Biol. Farm, 4(2): 100-106, 2010.

TOLEDO, Olegário R et al. Legal / Use of weight loss drugs and body mass index among academicians from Vale do Araguaia (MT/GO), Legal Amazon. Rev. Soc. Bras.

Clín. Méd, São Paulo, 8(6): 480-485, nov/dez, 2010. 